\section{EMBRYARIDDLE Aeronautical University}

SCHOLARLY COMMONS
International Journal of Aviation, Aeronautics, and Aerospace

\title{
Evaluating LAANC Utilization \& Compliance for Small Unmanned Aircraft Systems in Controlled Airspace
}

\author{
Ryan J. Wallace \\ Embry-Riddle Aeronautical University, ryan.wallace@erau.edu \\ John M. Robbins \\ Embry-Riddle Aeronautical University, robbinsj@erau.edu \\ Jon M. Loffi \\ Oklahoma State University - Main Campus, jon.loffi@okstate.edu \\ James K. Holliman \\ Embry-Riddle Aeronautical University, hollimaj@erau.edu \\ Donald S. Metscher \\ Embry-Riddle Aeronautical University, metscdb4@erau.edu \\ Taylor R. Rogers \\ Embry-Riddle Aeronautical University, ROGERT18@my.erau.edu
}

Follow this and additional works at: https://commons.erau.edu/ijaaa

\section{Scholarly Commons Citation}

Wallace, R. J., Robbins, J. M., Loffi, J. M., Holliman, J. K., Metscher, D. S., \& Rogers, T. R. (2020). Evaluating LAANC Utilization \& Compliance for Small Unmanned Aircraft Systems in Controlled Airspace. International Journal of Aviation, Aeronautics, and Aerospace, 7(2). https://doi.org/10.15394/ ijaaa.2020.1453

This Article is brought to you for free and open access by the Journals at Scholarly Commons. It has been accepted for inclusion in International Journal of Aviation, Aeronautics, and Aerospace by an authorized administrator of Scholarly Commons. For more information, please contact commons@erau.edu. 


\section{Evaluating LAANC Utilization \& Compliance for Small Unmanned Aircraft Systems in Controlled Airspace}

\section{Cover Page Footnote}

The research team would like to acknowledge the contributions of student researchers Joshua $\mathrm{G}$. Marcham and Francis M. Roden. 
The process of integrating of small unmanned aircraft into the National Airspace System has often been attributed as the "wild west" (Levin, 2018; Hofacker, 2019; Karpowics, 2019). This attribution stems from the perception of lax regulation and loose oversight of small unmanned aircraft operators, similar to the lawlessness and frontier justice of the American expansion into the west.

Following the passage of FAA Reform Act of 2018 (PL 115-254), however, the Federal Aviation Administration is quickly "taming the west" by imposing new flight restrictions on recreational and hobbyist drone operators. Most notable among these new restrictions are the changes to where recreational flyers are permitted to operate. Under previous rules, recreational operators were granted liberal access to fly near airports, provided they provided advanced notification to the airport operator or air traffic control tower (PL 115-95, Sec 336, Special Rule for Model Aircraft). This authority deviated significantly from 14 CFR $\S 107$, which required flyers to apply for a waiver to fly in controlled airspace (14 CFR §107.41).

\section{Low Altitude Authorization \& Notification Capability (LAANC)}

In April 2018, the Federal Aviation Administration began a nationwide rollout of an alternative, expedited means for Part 107 operators to receive approval to operate in controlled airspace. The Low Altitude Authorization and Notification Capability (LAANC) was designed as a collaborative data-sharing arrangement between the FAA and industry to support UAS integration into selected areas of low altitude, controlled airspace (FAA, 2019g). Using industry-designed and supported mobile and online applications, users can rapidly submit airspace requests for flight in controlled airspace. UAS user airspace authorization requests are provided to the FAA and approvals are transmitted to the user in near-real time, enabling rapid access to controlled airspace. The LAANC system "automates the application and approval process for airspace authorizations" by validating electronic airspace requests with airspace data derived from "UAS Facility Maps, Special Use Airspace data, Airports and Airspace Classes, as well as Temporary Flight Restrictions (TFRs) and Notices to Airmen (NOTAMs)" (FAA, 2019g, p. 1). On July 23, 2019, the FAA announced the expansion of LAANC approval authority to include model aircraft and hobbyist flyers (FAA, 2019e).

The agency reports that LAANC is available at 595 airports, which includes FAA air traffic control facilities and more than 100 contract towers manned by private companies (FAA, 2019a; FAA, 2019f). In the nearly two years since its inception, LAANC has received and processed more than 170,000 airspace authorizations (FAA, 2019d).

\section{Problem}

According to the docket filed by the FAA, "LAANC is expected to dramatically reduce the incidence of noncompliant operations. The FAA estimates a minimum of $30 \%$ reduction in noncompliance operations would result in 450 
fewer safety reports over the next six months [time period ending circa April 2018]" ("Request," 2017, p. 47289). Rupprecht (2019) identifies a key flaw in the FAA's implementation of LAANC: "LAANC does not tell us if it fixed the problem it is attempting to alleviate" (p. 1).

Rupprecht's (2019) criticism is not without merit-little data has been published regarding the effectiveness of the LAANC system in reducing UAS encounters with aircraft. Figure 1 depicts UAS sightings or encounters reported by pilots, controllers, and other aviation stakeholders. From November 2014 through June 2019, the agency has amassed 8,615 sighting reports, an average of 153 incidents per month. Table 1 highlights the growth trend of UAS sighting reports, based on the number of reported monthly sightings.

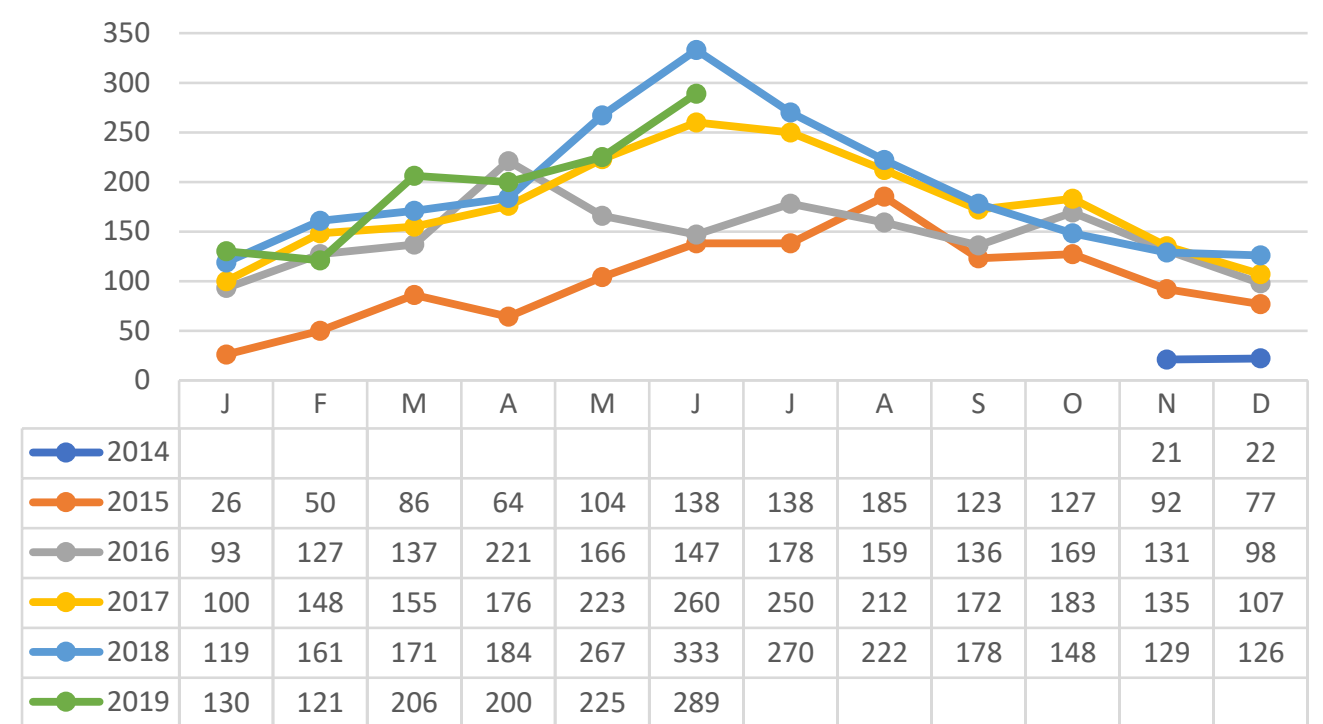

Figure 1. UAS Sighting Reports (Nov 2014-Jun 2019) (derived from FAA, 2019h).

Table 1

UAS Sighting Report Trend Data

\begin{tabular}{llll}
\hline Year & Total Sightings Reports & Average / month & Change Y/Y (\%) \\
\hline 2014 & $43^{*}$ & $21.5^{*}$ & N/A \\
2015 & 1,210 & 100.8 & $369.0 \%$ \\
2016 & 1,762 & 146.8 & $45.6 \%$ \\
2017 & 2,121 & 176.8 & $20.4 \%$ \\
2018 & 2,308 & 192.3 & $8.8 \%$ \\
2019 & $1,171^{* *}$ & $195.2^{* *}$ & $1.5 \%$ \\
\hline
\end{tabular}

Notes: *Two months of data reported; **Six months of data reported. 
While the data indicates the annualized growth of sighting reports has been largely curtailed, it is not possible to identify the cause of this trend shift.

An additional criticism of the LAANC system is highlighted by Law360 (2019), "even assuming hobbyists and commercial operators alike can obtain nearreal-time authorizations to operate in restricted airspace nationwide, this only provides a mechanism for law-abiding drone operators to utilize the airspace - it doesn't stop the rogue operators [emphasis added]" (p. 1).

\section{Purpose}

The purpose of this research was to codify LAANC effectiveness by comparing LAANC authorizations against UAS flight activity identified using UAS detection equipment. The research team correlated detected UAS flight activity with corresponding LAANC authorizations, based on UAS origination location and operating timeframe.

\section{Research Questions}

The research team sought to answer the following questions:

1. What proportion of detected UAS activity carried out in controlled airspace can be correlated to a LAANC authorization?

2. What proportion of detected UAS activity exceeds the maximum prescribed altitudes of the UAS Facility Map?

\section{Method}

The research team employed an exploratory approach for this project, leveraging primarily quantitative data. A DJI AeroScope UAS detection device was deployed to capture UAS flight activity in proximity to Daytona Beach International Airport (KDAB). This project was approved by IRB Protocol 118114.

\section{Sample Selection}

Researchers selected the convenient sample location due to the relatively high number of historical UAS flights in the region and the fixed position of AeroScope equipment. Researchers estimate the sample location is home to approximately 649 Part 107 UAS operators and 1,147 recreational UAS operators, based on data obtained from the FAA's Drone Registration Database (see Figure 2). The researchers emphasize that data collection from the selected sample location may not necessarily be representative. 


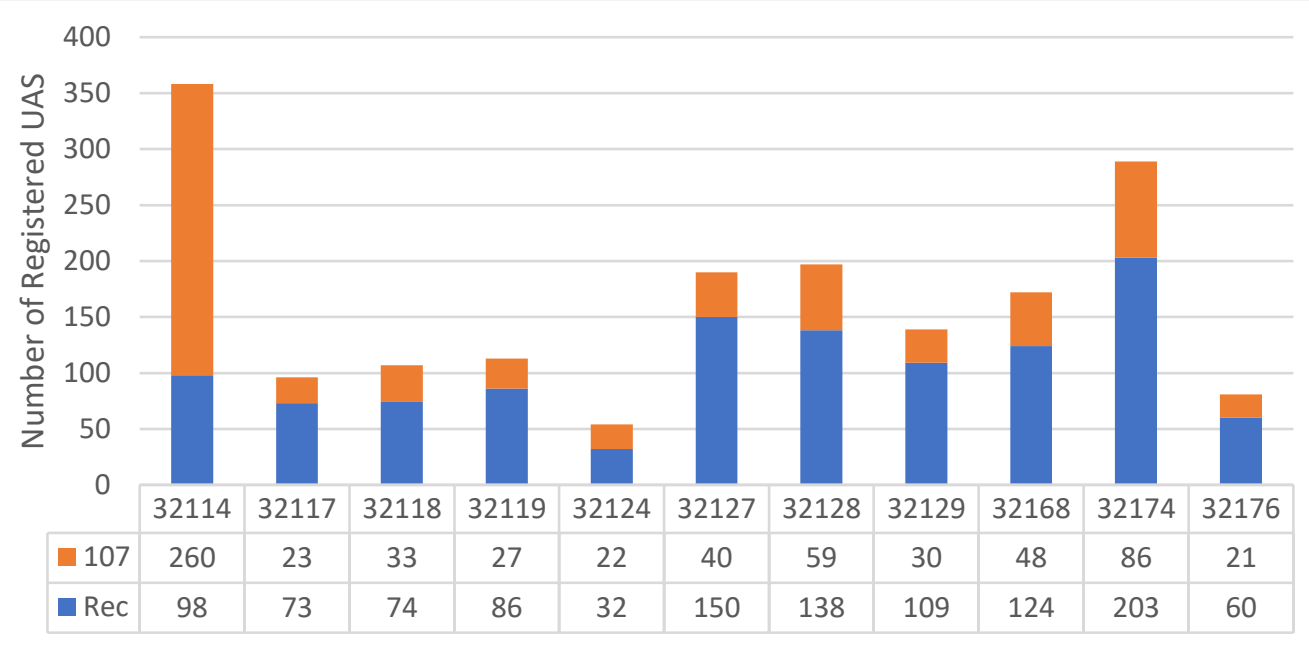

Figure 2. UAS Registrations in proximity to Daytona Beach International Airport by zip code, current as of CY2019Q4 FAA, 2019c). Note FAA-reported Part 107 registrations for 32114 totaled 960, however, this number was moderated to 260 due to a state grant-funded program in Daytona Beach registering an estimated 700 sUAS that are administratively managed from Daytona Beach, but not physically operated in the area.

\section{Data Collection Instrument}

The AeroScope device passively detects, identifies, and tracks UAS platforms using communications signals. In the deployed configuration, the standalone AeroScope is capable of unsupervised, 24-hour, all-weather detection of small unmanned aircraft systems. The device gathers detailed information including UAS model, status, flight path, home (launch) point, altitude, and other related information in real-time.

It is important to note that the device does not detect all unmanned aircraft systems - only those manufactured by DJI. Exact estimates of DJI market share within the U.S. consumer drone industry vary. Research group Drone Industry Insights (2019) estimates that DJI market share exceeds 76.8\%. A previous report by Skylogic Research (2018) estimated DJI commanded an estimated 74\% market share.

\section{Data Collection \& Analysis Procedure}

Researchers collected AeroScope detection data for a period of 30 days. Collected data included detection date / time, drone type, drone ID, flight ID, latitude / longitude, home (launch) location, and pilot location. Researchers considered all co-located UAS activity with matching drone ID performed within a 30-minute time period to be a singular operation. The dataset was cleaned to reconstruct split datasets in which a singular UAS operation was divided among several flights due to short detection interruptions. The location of each UAS 
operation was extracted from the dataset by evaluating the UAS home point, operator location, and initial UAS detection location. Summary statistics were calculated for all detected UAS operations to assess operator behaviors. Tabular datasets were further converted to Keyhole Markup Language (KML) format for analysis purposes using Earth Point. Earth Point imports geolocation data, icons, paths, and polygons; and, supports advanced features such as GPS tracks, time sliders, and grid coordinates (Clark, 2019).

Current UAS Facility Map (UASFM) KML data was downloaded, based on agency source material (FAA, 2019b). The complex 36-character GLOBALID of UASFM boxes were converted for simplicity to representative, sequential numerical values for the sample location, referred to throughout this report as the UASFM Coding Schematic (see Figure 3). Researchers manually coded UAS detection location data to the accompanying UASFM grid of origin.

Following the completion of the sample detection period, LAANC approval data was requested from the FAA. The furnished LAANC Approval Data included request type, start date / time, location, altitude status, and reference ID. LAANC approval location data did not include grid information. Instead LAANC request locations were identified by a bearing and range from the airport reference point. Researchers manually coded LAANC approval locations to the UASFM Coding Schematic.

UAS detection data and LAANC approval data were compared to evaluate UAS detections and LAANC approvals over a period of time. Since the LAANC approval system cannot correlate to a specific UAS platform, the researchers determined that UAS activity detected within the same UASFM grid and timeframe as an active LAANC approval would be considered an approved UAS operation. 

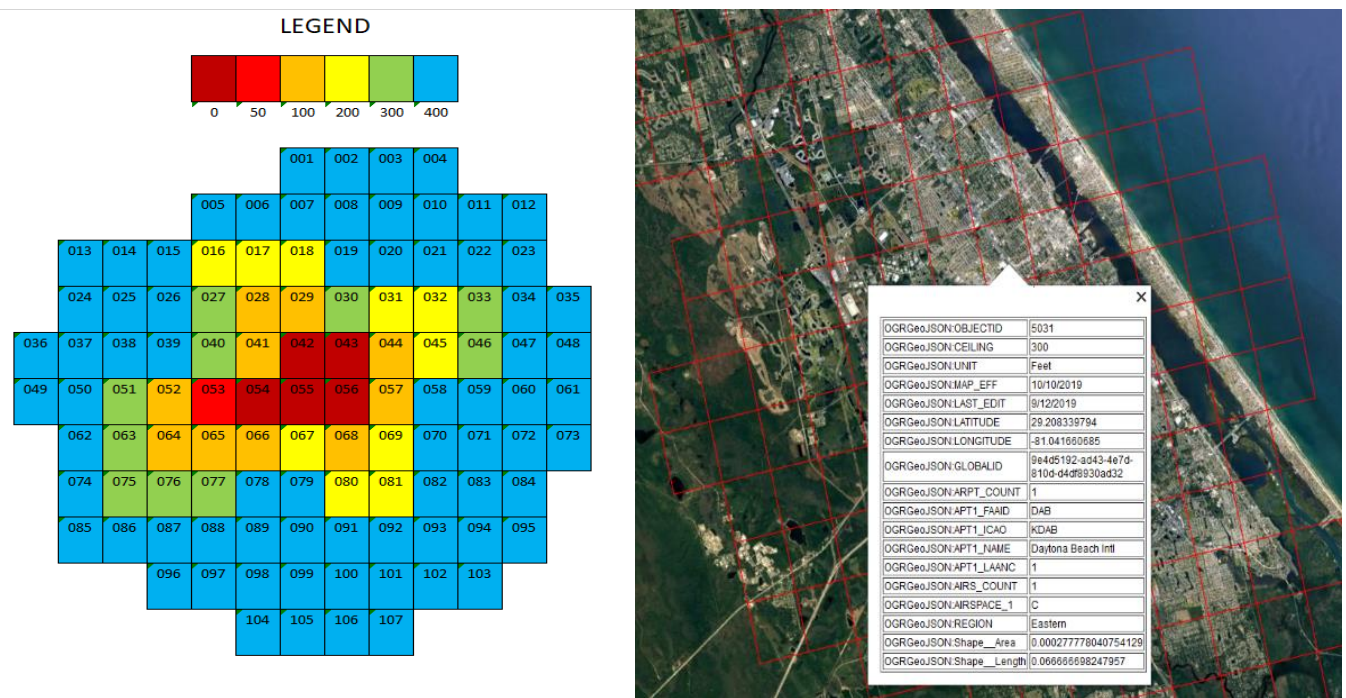

Figure 3. [Left] UASFM Coding Schematic used for project. [Right] Excerpt of UASFM KML Data (FAA, 2019b). Note: the selected UASFM grid box on the right would correspond to grid 30 on the left coding schematic.

\section{Results \& Discussion}

Researchers collected UAS detection data for a total of 30-days, divided into two timeframes. While the research team sought to collect during a consecutive period, the AeroScope needed to be taken offline from August 30 at 9:00am (ET) to September 7 at 11:00am (ET) to secure the device from damage during Hurricane Dorian. Detection data was successfully collected for the first period from August 14, 2019 at 9:00am (ET) to August 30, 2019 at 9:00 am (ET). Detection data for the second period was collected from September 8, 2019 at 9:00am to September 22, 2019 at 9:00am (ET).

During the sample period, 272 UAS operations were detected. One of the UAS operations fell outside the UASFM grid, leaving 271 useful datasets (see Figure 4). During the sample period, 94 LAANC approvals were granted or active within the KDAB UASFM grid, including: 41 Part 107 approvals (43.6\%), 24 recreational approvals (25.5\%), and 29 manually-processed approvals (30.9\%). 


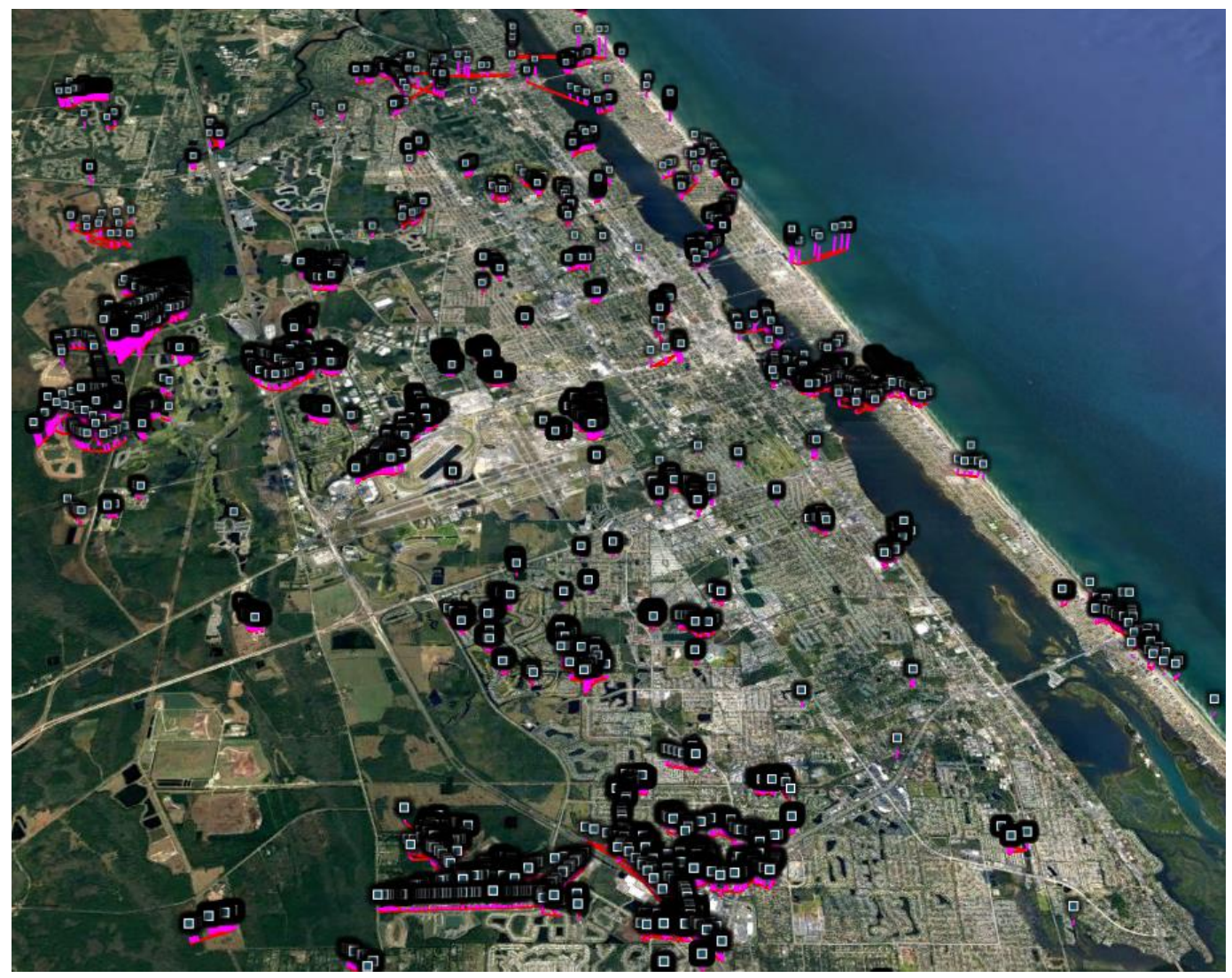

Figure 4. sUAS Detections in proximity to Daytona Beach International Airport (KDAB), August 14-September 22, 2019, displayed with telemetry.

\section{Operation Duration}

Automatic LAANC requests ranged in duration from as little as 15 minutes to as long as 24 hours. The mean duration for all requests was 3:10:11 (Part 107 mean $=4: 09: 57$, Recreational $=1: 23: 05)$. The median duration for all LAANC requests was 1:00:00, with the median durations for both Part 107 requests and Recreational category requests being 1:00:00. The $S D$ for all requests was 9:33:30. Figure 5 shows the distribution of LAANC approvals, based on duration. 


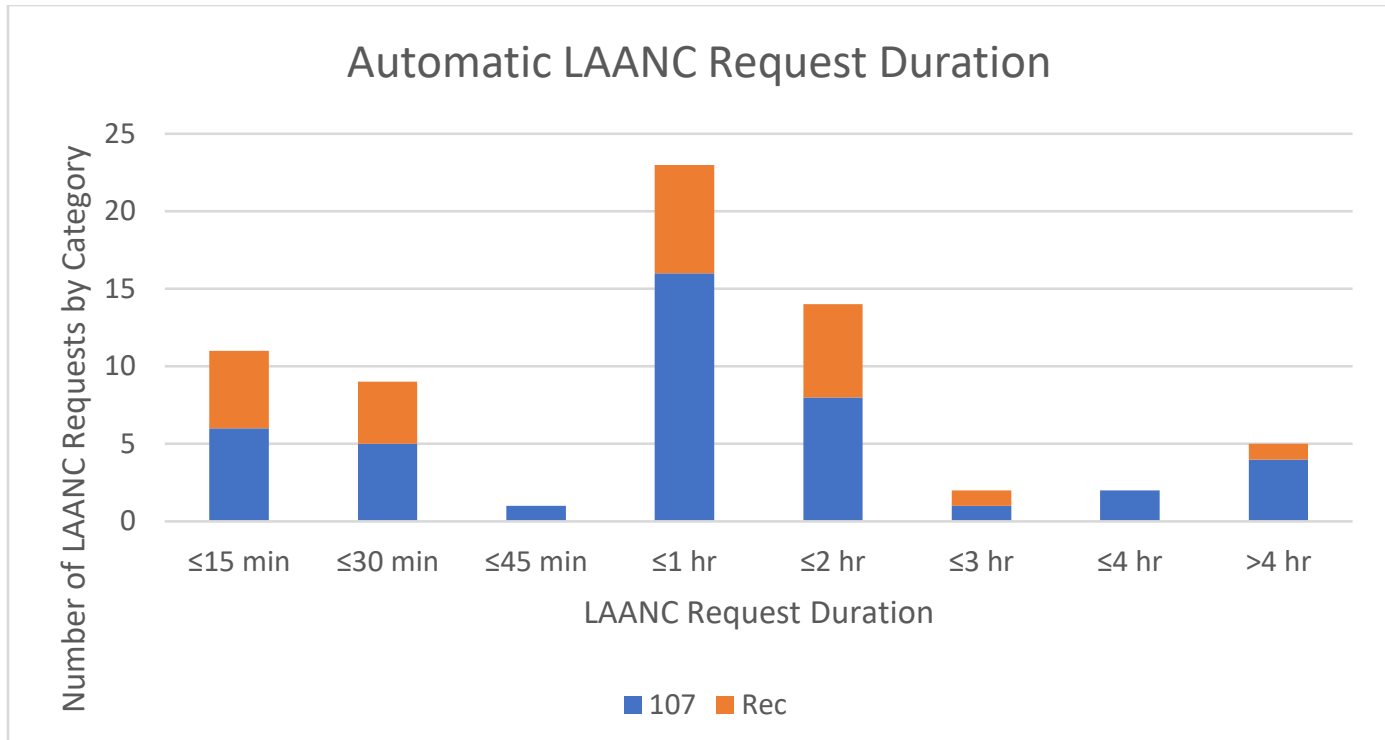

Figure 5. Automatic LAANC Request Duration by Operation Type. Duration bins are presented independently and exclude previous bins (i.e. " $30 \mathrm{~m}$ " bin represents $15 \mathrm{~m}<t \leq 30 \mathrm{~m})$.

The mean duration of detected UAS activities was 12:14, with the median duration being 5:01 $(S D=27: 39)$. Thirty-two detections $(11.8 \%)$ included only momentary activity - a singular UAS detection that failed to provide duration information. The distribution of detected durations is heavily right-skewed, with $74.3 \%$ of UAS operations lasting durations of less than 10 minutes (see Figure 6).

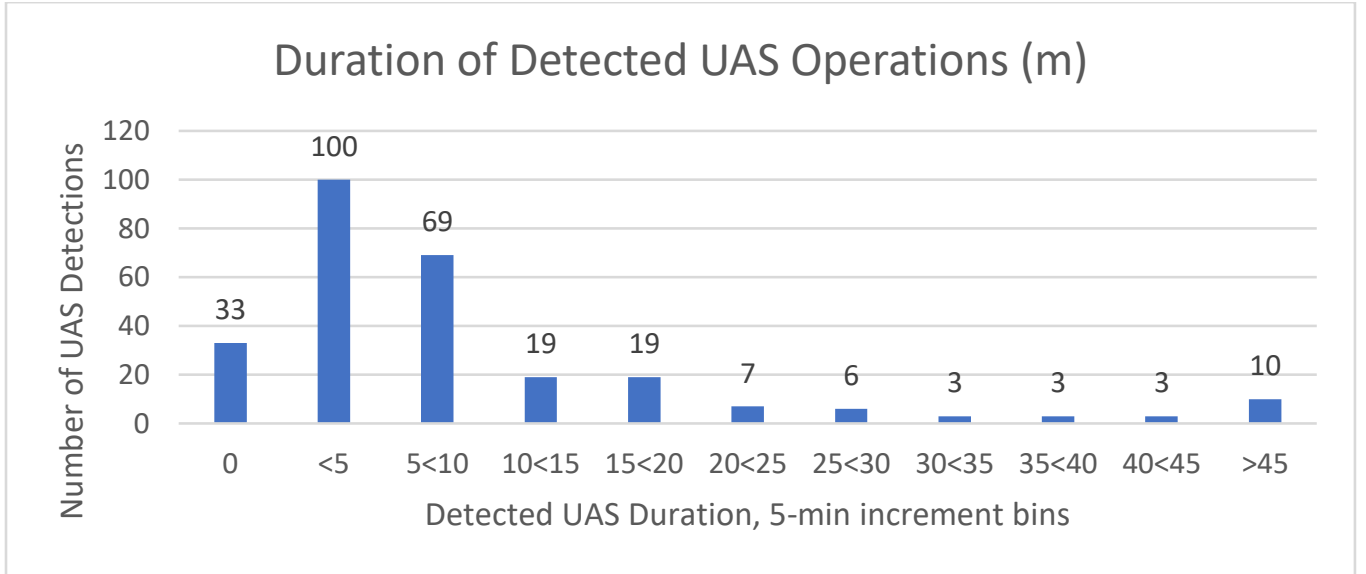

Figure 6. Duration of Detected UAS Operations (plotted in minutes).

It is particularly notable that approval durations vastly exceeded the length of time of UAS detections, by a factor of nearly 20-1 (based on median values). 
This indicates that LAANC approval durations do not accurately reflect the duration of LAANC grid utilization. This can be problematic, as long-duration LAANC approvals obscure when UASFM grid areas actually contain UAS activity. Operational Date/Time

The LAANC system received and approved a mean of 1.9 automated LAANC requests per day, with a mode of 2 requests $(S D=2.1)$. UAS detections averaged 8.2 per day, with a median of 8 per day $(S D=3.1)$. Automated LAANC approvals were somewhat inconsistent over the sampling period, and the overall daily approval rate remained relatively low. Results are presented in Figure 7.

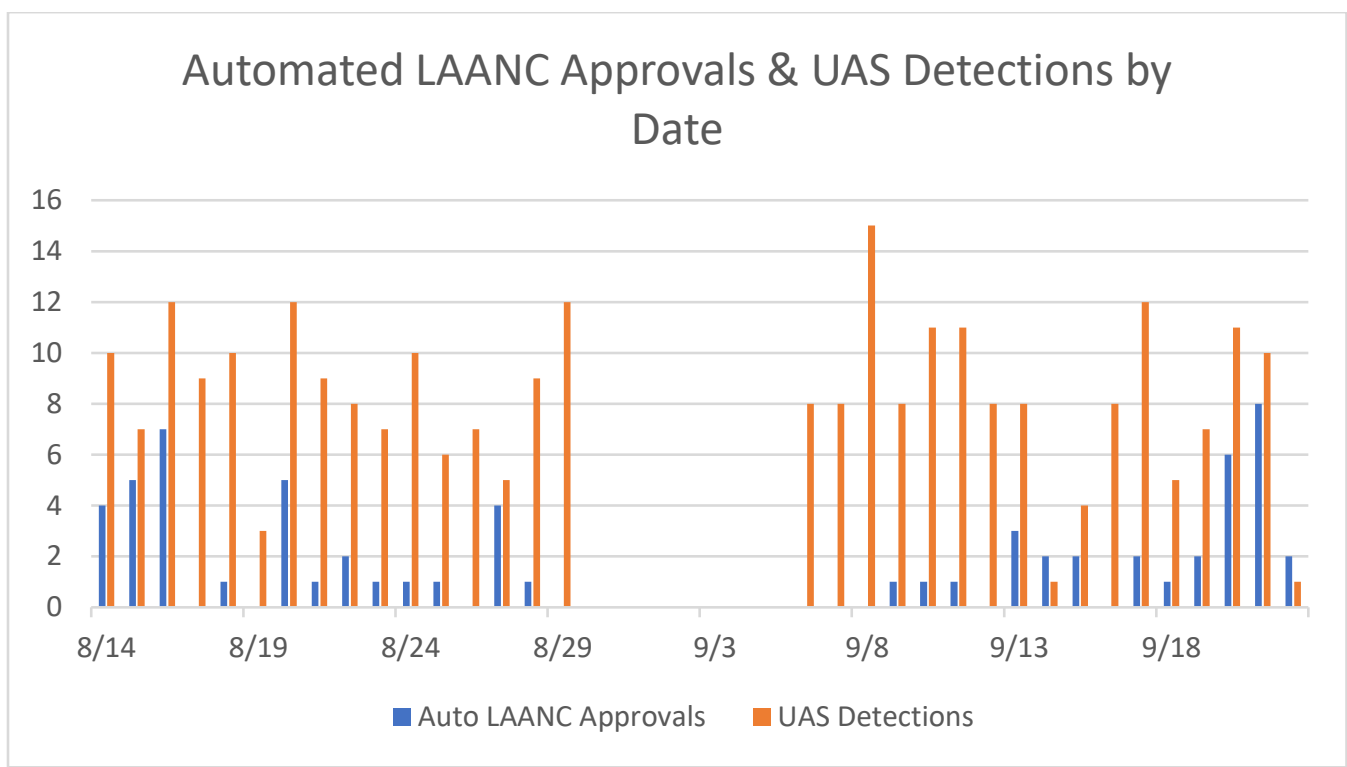

Figure 7. Automated LAANC Approvals and UAS Detections by (Local) Date.

The research team assessed both automated LAANC approvals and UAS detections by day of week, to evaluate for possible trend patterns (see Figure 8). Generally, automated LAANC approvals remained fairly stable, with diminished activity on Mondays and slightly higher activity on Fridays. UAS detections show a dip in activity on Mondays, but remain relatively consistent throughout the remainder of the week. The researchers do not have an explanation for the variability of automated LAANC approvals or detections between various days of the week. 


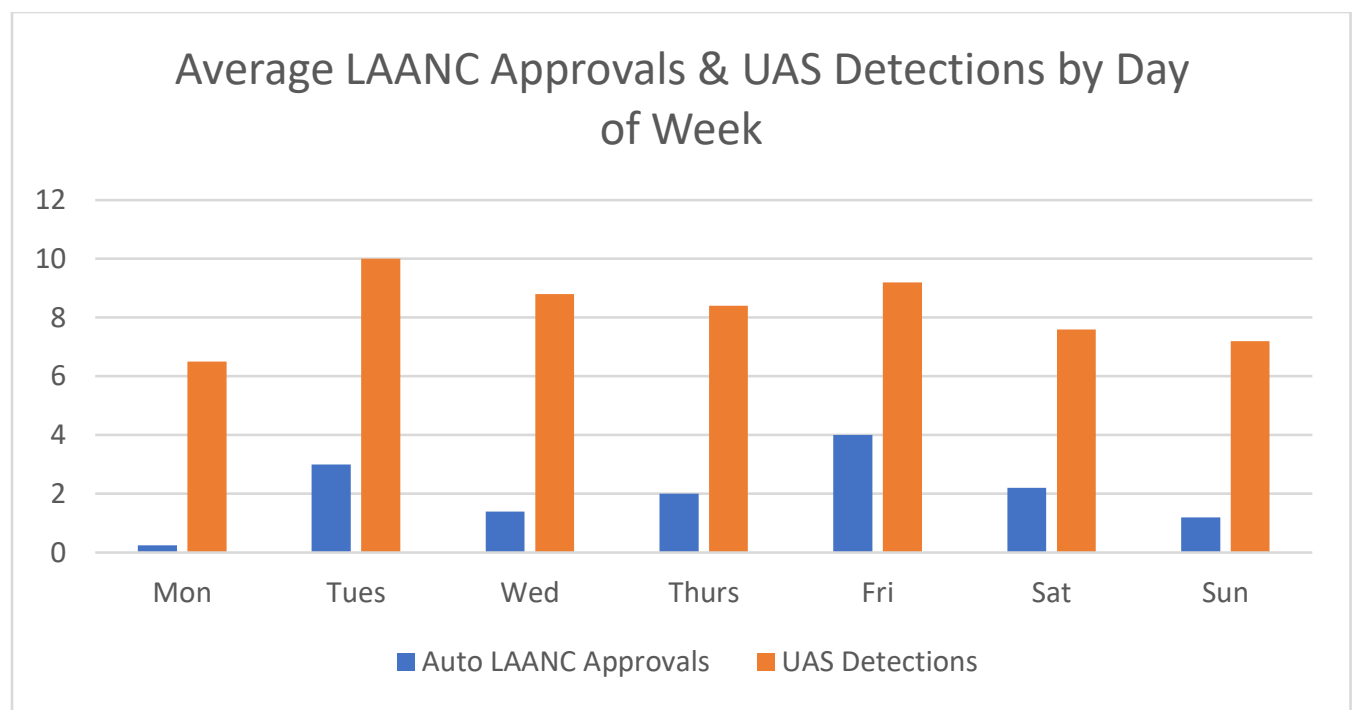

Figure 8. Average Number of Automatic LAANC Approvals \& UAS Detections by Day of Week (based on Local Date).

An evaluation was also performed on the time of day for automated LAANC approvals and UAS detections (see Figure 9). Both LAANC approvals and UAS detections follow relatively consistent patterns, with activity increasing during morning daylight hours and diminishing after hours of darkness.

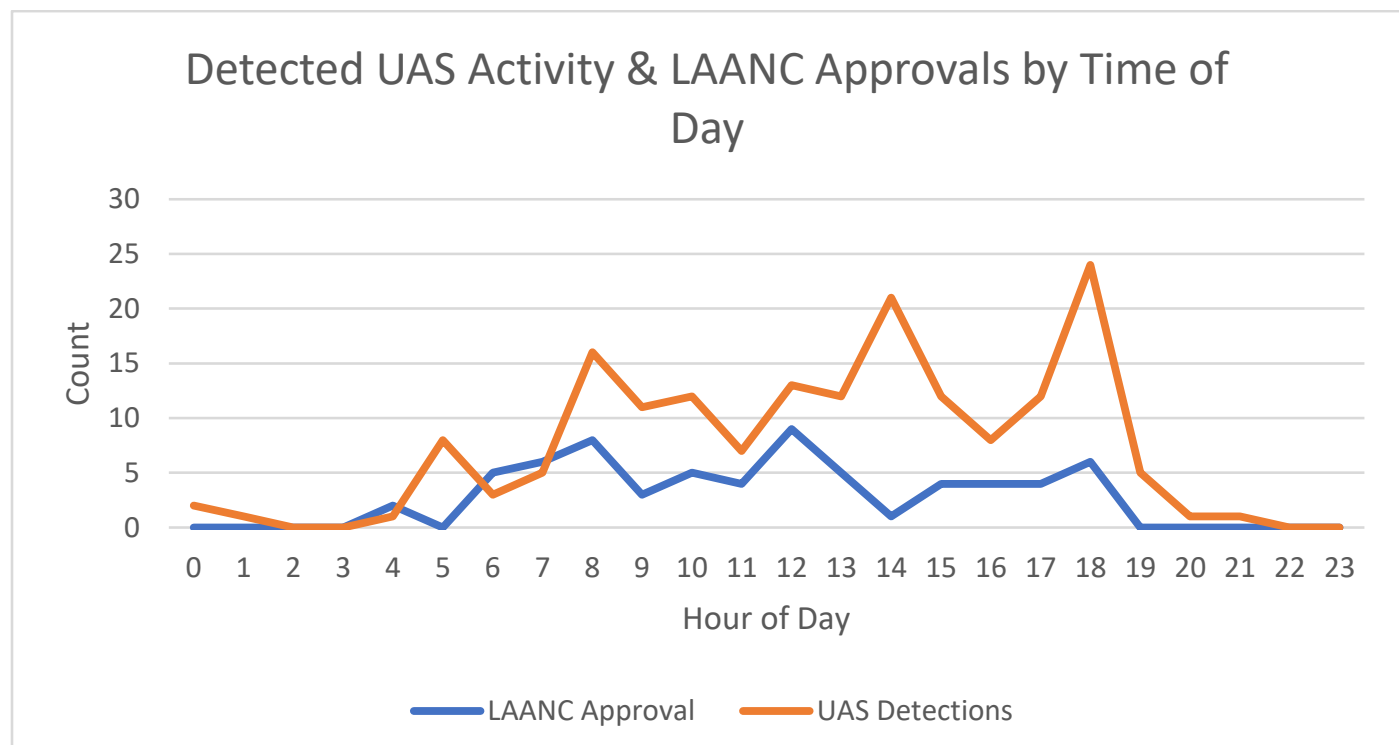

Figure 9. Detected UAS Activity \& Auto LAANC Approvals by Time of Day, (24hour clock, Local Time). 


\section{UASFM Grid Utilization}

The research team evaluated the overall utilization of airspace within the LAANC system, assessing both automated LAANC approvals and UAS detections based on UASFM maximum altitude grids. Automated LAANC requests and UAS detections within each altitude grid appear to be consistent with each grid's proportion within the UASFM architecture for the sample location. Utilization for 400-foot grids was most prominent, outpacing utilization of other grid types by approximately four to one. Researchers had anticipated that lower altitude gridsthose closer to airports and critical aeronautical activities-would receive significantly higher utilization, however the data did not support this presumption. Results are presented in Figure 10.

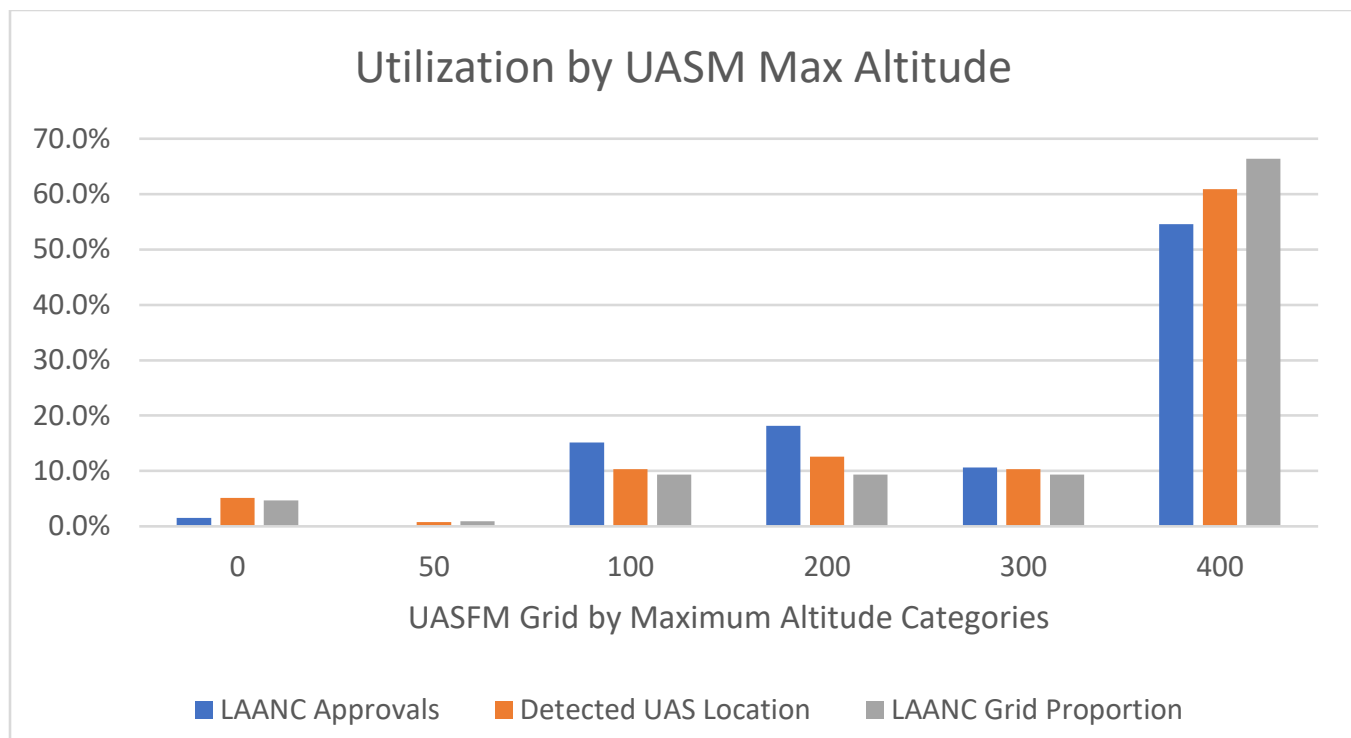

Figure 10. LAANC Utilization by UASFM Max Altitude. This chart compares LAANC requests in the six maximum altitude areas to the proportion of the UASFM grid made up by those areas.

To better illustrate LAANC grid utilization, the researchers plotted usage on a 3-D depiction of the UASFM grid system. UASFM grids are colorized based on maximum altitudes (see Figure 11). The data suggests that LAANC requests tend to be clustered in high-utilization areas. The data seems to indicate that a slightly higher proportion of LAANC requests are being sought for lower-altitude, near-airport grids. Conversely, UAS detection results showed that utilization within the UASFM system was much more variable. This may suggest that UAS operators flying very near airports are more cognizant of flight restrictions or potential safety implications. Alternatively, this data may suggest that many operators may still be flying under the rescinded Special Rule for Model Aircraft. Section 336 of PL 112- 
95 provided special provisions for model aircraft operations, which included wide latitude for operating locations, provided the operator provide notification to any airports within 5 miles (FAA Modernization \& Reform Act of 2012).

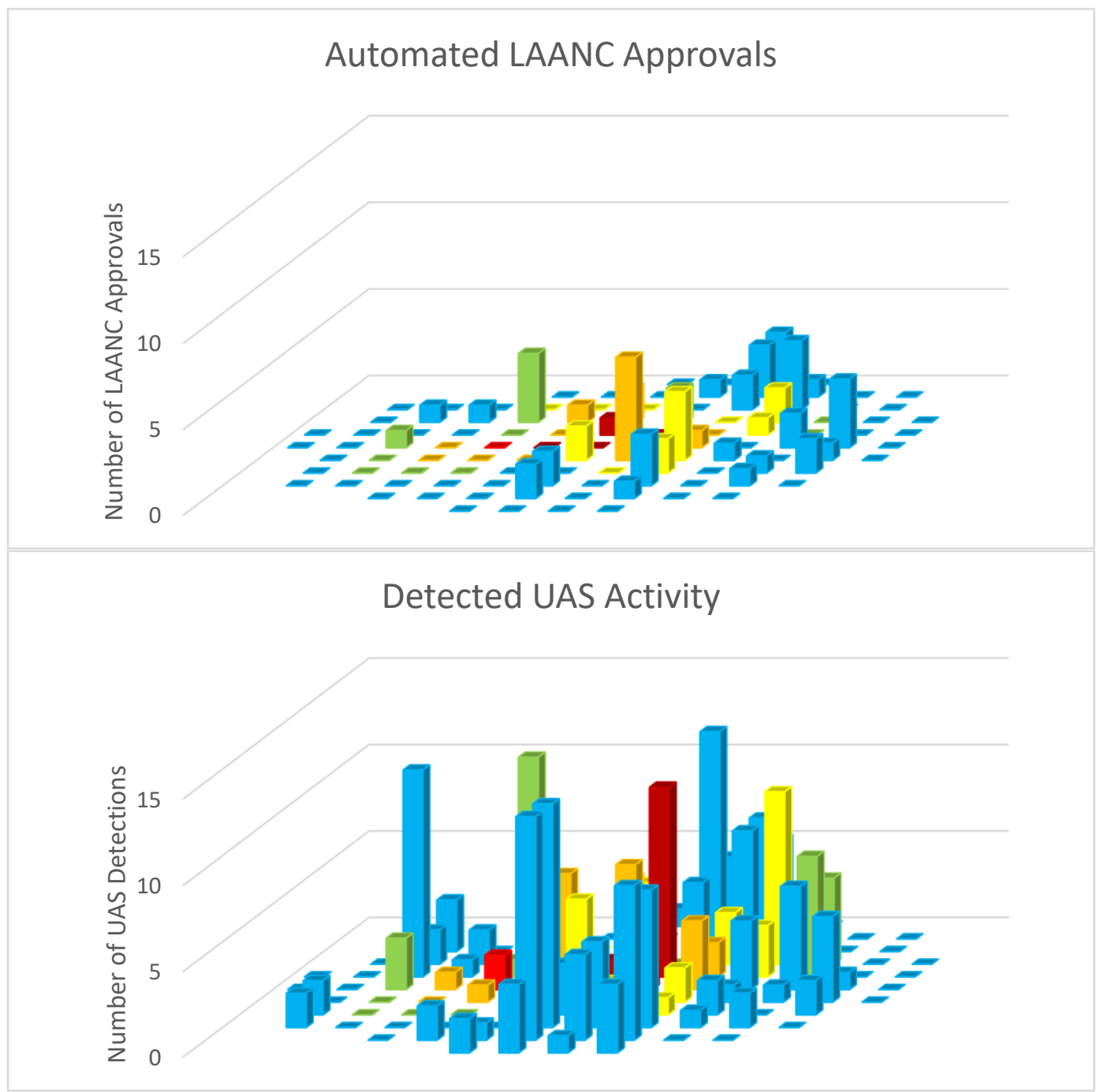

Figure 11. [Top] 3-D Depiction of Automated LAANC Requests during sampling period using 3-D representation of UASFM Coding Schematic. [Bottom] 3-D Depiction of Detected UAS Activity in LAANC grids during sampling period. Note: Grid colors represent maximum UASFM altitudes: Blue $=400 \mathrm{ft}$; Green=300 $\mathrm{ft}$; Yellow=200 ft; Orange $=100 \mathrm{ft}$; Light Red=50 ft; Dark Red=0 ft. Y-axis represents quantity of [Top] LAANC approvals or [Bottom] UAS detections within the respective grid. 


\section{Compliance with UASFM Maximum Altitudes}

When comparing UAS detection data against corresponding UASFM grid locations, the research team revealed several concerning findings. Only 177 $(65.3 \%)$ of detected UAS platforms fell within prescribed altitude limits for their respective UASFM grid location. Figure 12 shows all UAS detections organized using the UASFM Coding Schematic, with maximum UASFM grid altitudes depicted.

Particularly high-altitude UAS flights demonstrated elevated risk to National Airspace System safety, since sUAS operations remain mostly segregated from manned aircraft operations. At least $41(15.1 \%)$ UAS operations were detected above 500 feet AGL. Of these UAS operations, 32 (11.8\%) were above 500 feet AGL; 6 (2.2\%) were detected above 1,000 feet AGL; and 3 (1.1\%) exceeded 1,500 feet AGL (see Figure 13).

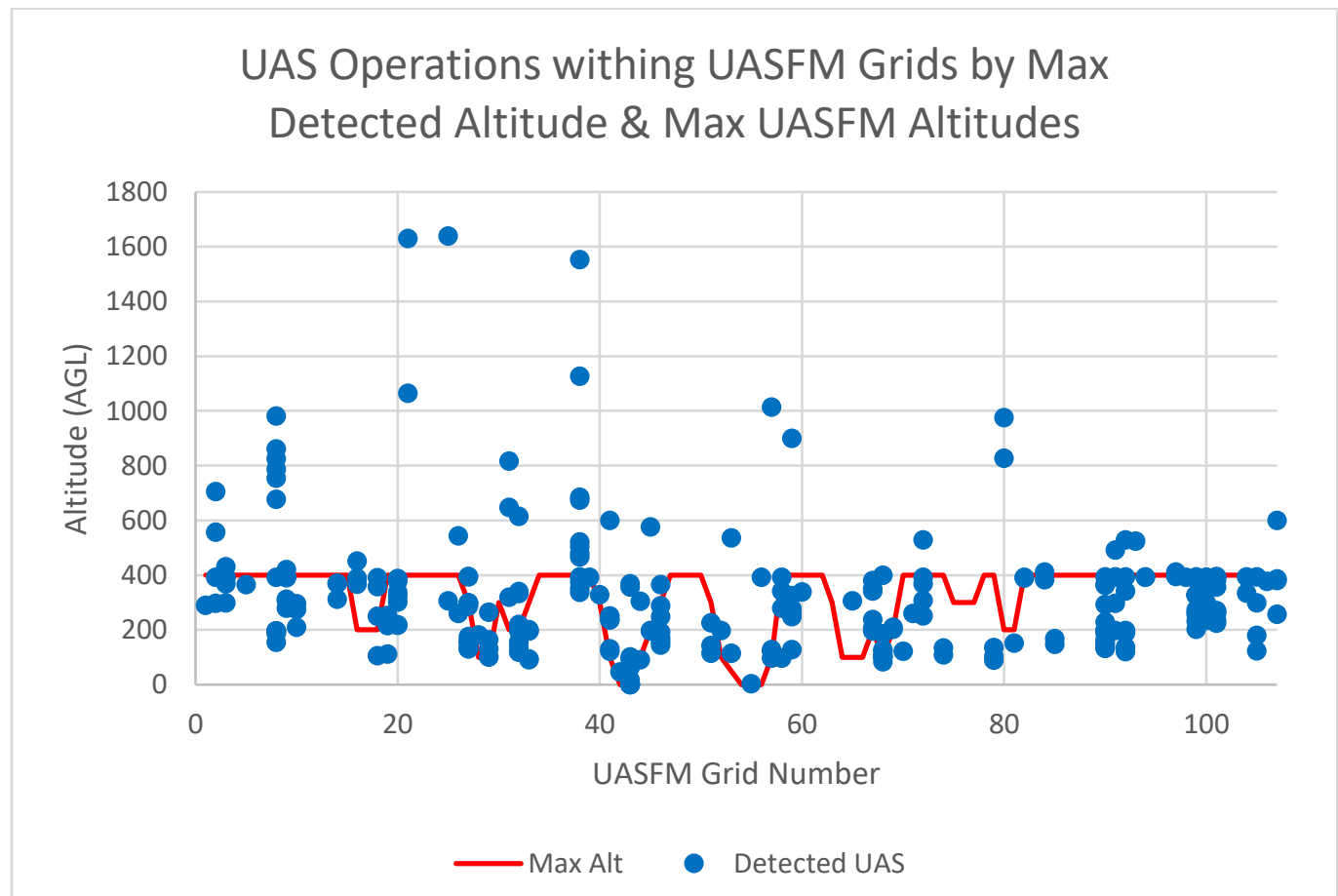

Figure 12. UAS Operations within UASFM Grids by Max Detected Altitude \& Max UASFM Altitudes (plotted using UASFM Coding Schematic, measured in $\mathrm{ft}$ AGL). The red line indicates the maximum prescribed altitude within that segment of the UASFM grid. 


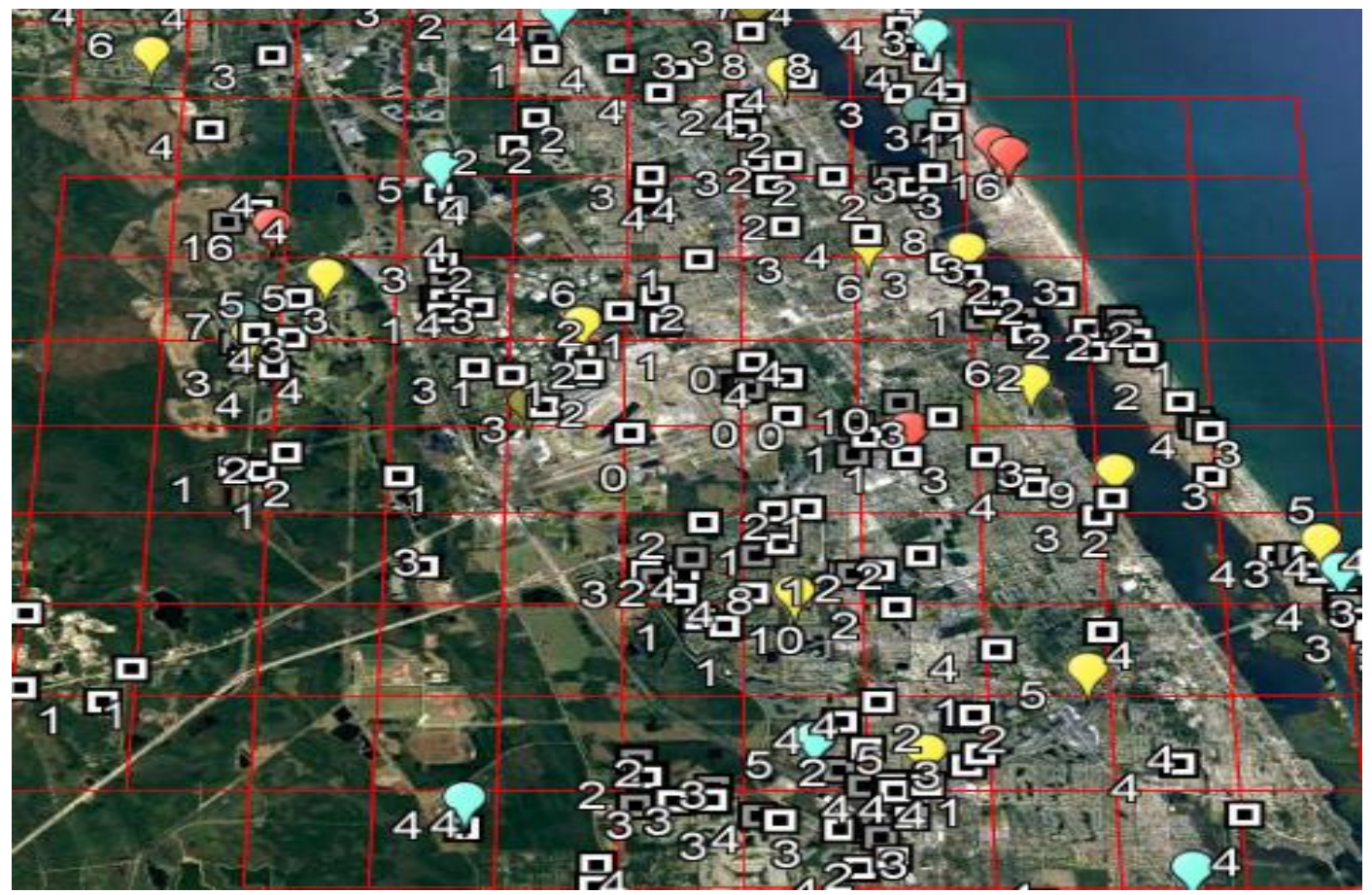

Figure 13. Depiction of detected sUAS origination locations within KDAB UASFM grid. Numerals indicate max detected altitude to nearest hundred feet AGL. White markers are less than $400 \mathrm{ft}$; cyan markers are 400-499 ft AGL; yellow markers are 500-999 ft AGL; red markers are 1,000+ ft AGL.

Researchers attempted to ascertain the altitude safety margin for detected UAS operating within UASFM grids. Figure 14 shows the altitude safety marginthe altitude below the prescribed UASFM maximum-for all detected sUAS operations during the sampling period. This is essentially a measure of the level of risk a UAS flight presents to the National Airspace System, as UAS flights that significantly exceed their prescribed UASFM max altitude are no longer segregated from manned traffic and more likely to pose a collision risk. Of the 271 detected sUAS operations, 93 (34.3\%) were detected above the UASFM grid maximum for their respective location. Twenty-six UAS $(9.6 \%)$ were detected within than 50 feet above the UASFM maximum for the location; 13 (4.8\%) were within 100 feet; and $55(20.3 \%)$ exceeded 100 feet above the maximum UASFM altitude prescribed for their location. 


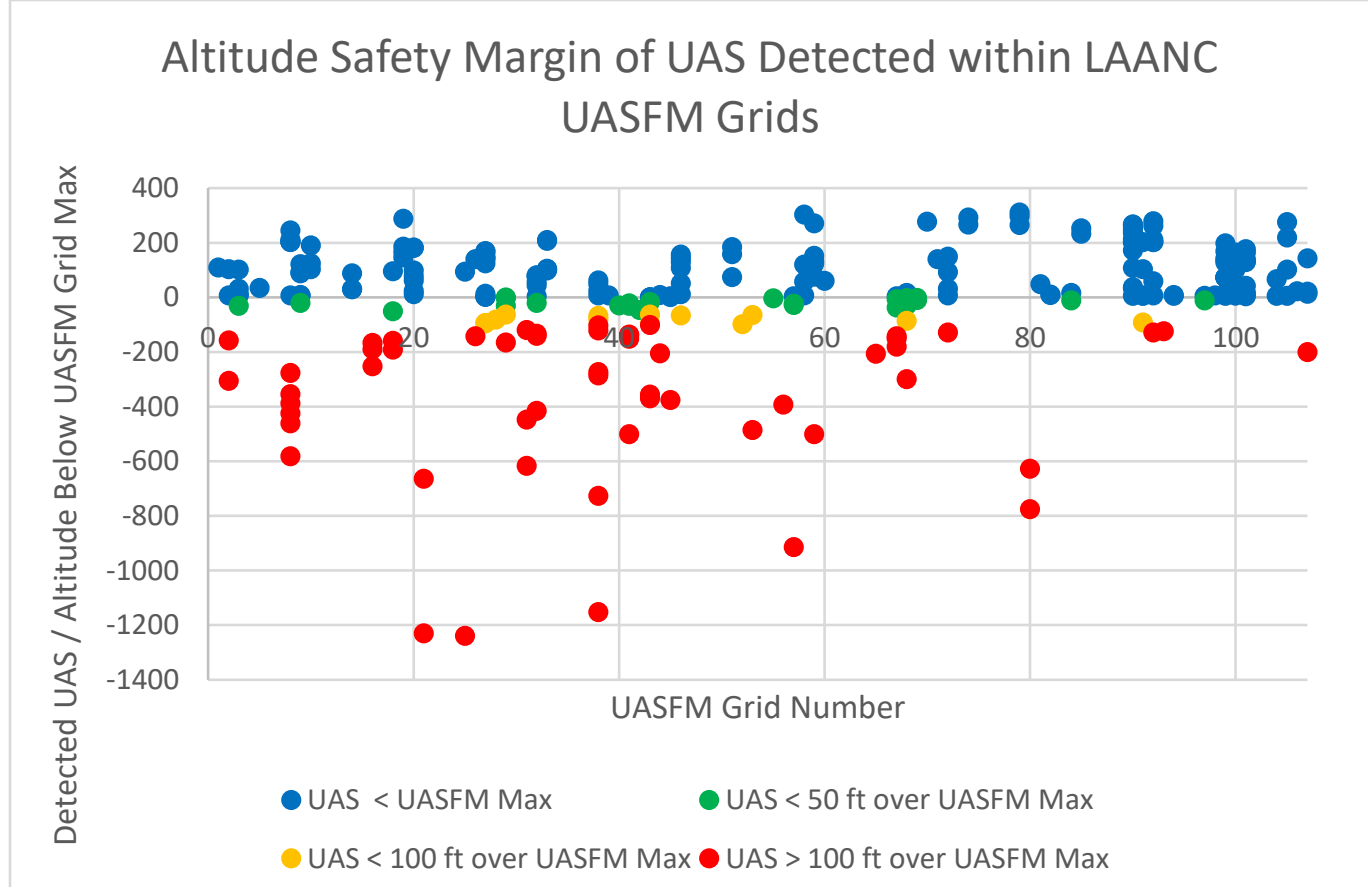

Figure 14. Altitude Safety Margin of UAS Detected within LAANC UASFM Grids. This chart compares detected UAS flight altitudes for flights carried out within UASFM grid (regardless of approval status) against UASFM maximum grid altitudes. UAS flights carried out below the prescribed maximum grid altitude are displayed in blue, with their margin below maximum plotted in $(+)$ feet. UAS flights carried out above UASFM prescribed altitudes are shown with negative safety margin values. Flights detected less than 50 feet above prescribed UASFM maximum for their grid are plotted in green; less than 100 feet above maximum in orange; and greater than 100 feet above maximum in red.

\section{Compliance with LAANC Authorizations}

When researchers attempted to correlate LAANC approvals with UAS detections, only 19 of the 271 detected UAS flights (7.0\%) could be matched to LAANC authorizations within the same grid (see Figures 15-20). It is difficult to ascertain why so few flights could be correlated to LAANC authorizations. The researchers propose the following possible explanations:

- LAANC authorizations were not sought for the UAS flights

- While LAANC authorizations were sought, some UAS operations were not flown

- Some LAANC authorizations included models of UAS that were not detectable by the AeroScope device. 
- While LAANC authorizations were received for specific areas, it is possible some UAS operators did not originate flights from within the area in which authorization was received.

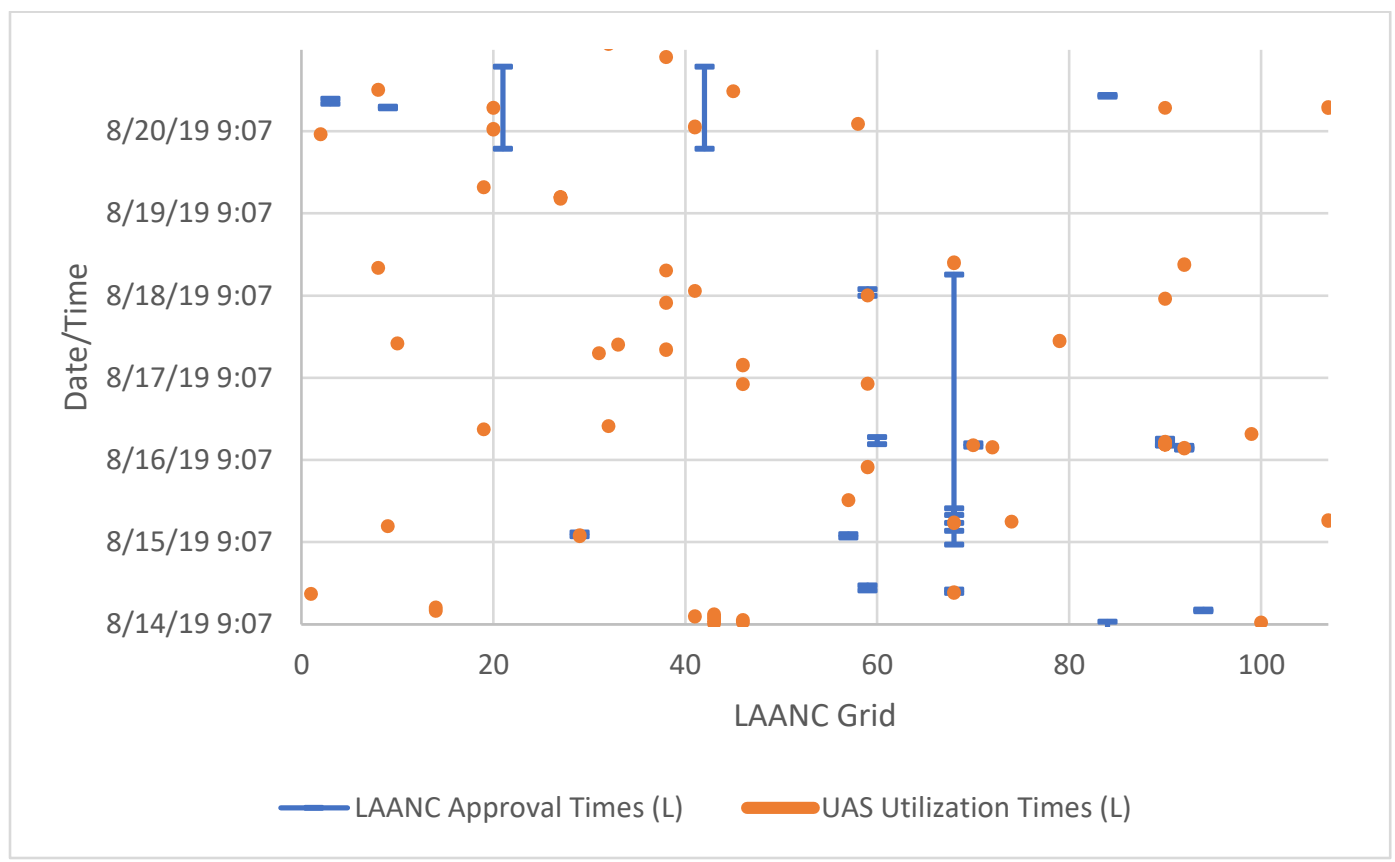

Figure 15. Low Altitude Authorization \& Notification Capability Utilization Daytona Beach International Airport, FL (KDAB), 14 Aug 19 0900L - 21 Aug 19 0859 L. LAANC approvals and detected UAS operations are plotted within their respective grid, based on the UASFM Coding Schematic (X-axis) and Date/time (y-axis). UAS operations that correlate with an accompanying LAANC authorization are depicted as an orange UAS utilization plot aligned within a blue LAANC approval. 


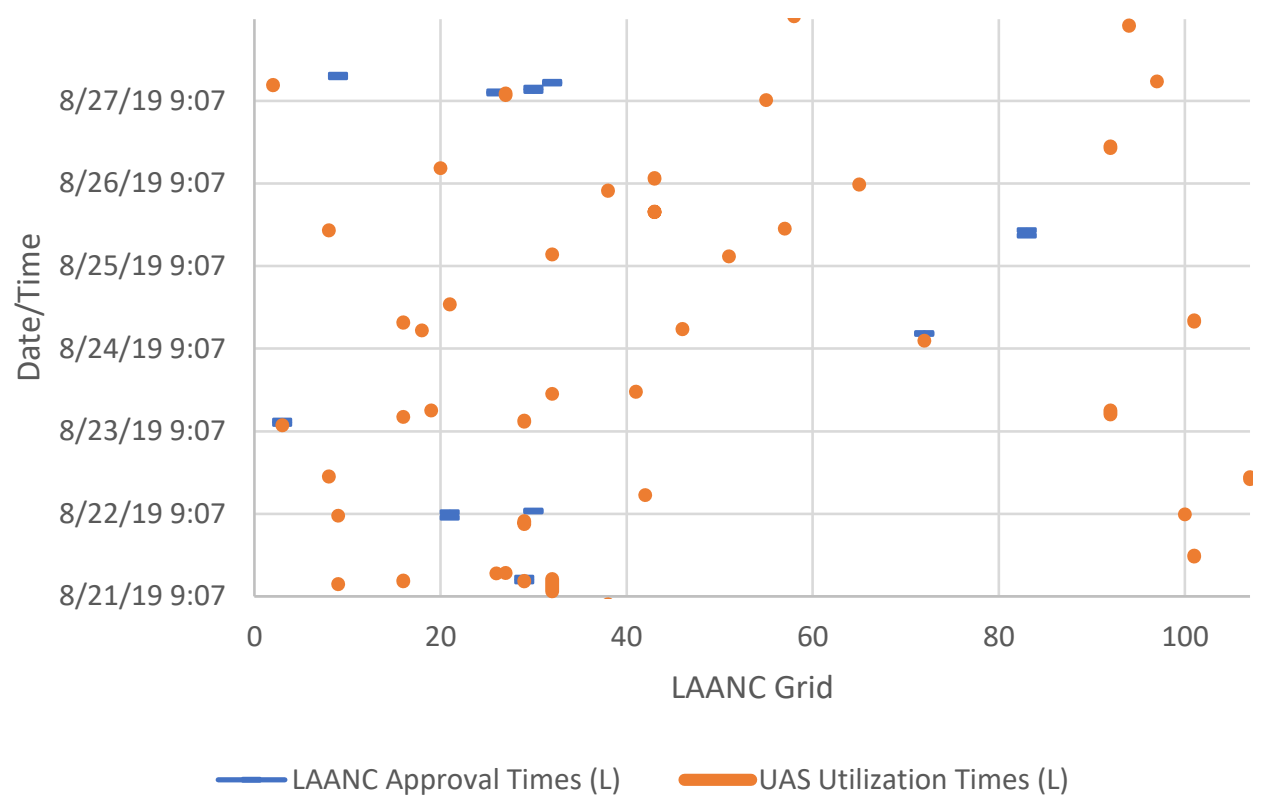

Figure 16. Low Altitude Authorization \& Notification Capability Utilization, KDAB, 21 Aug 19 0900L - 28 Aug 19 0859 L.

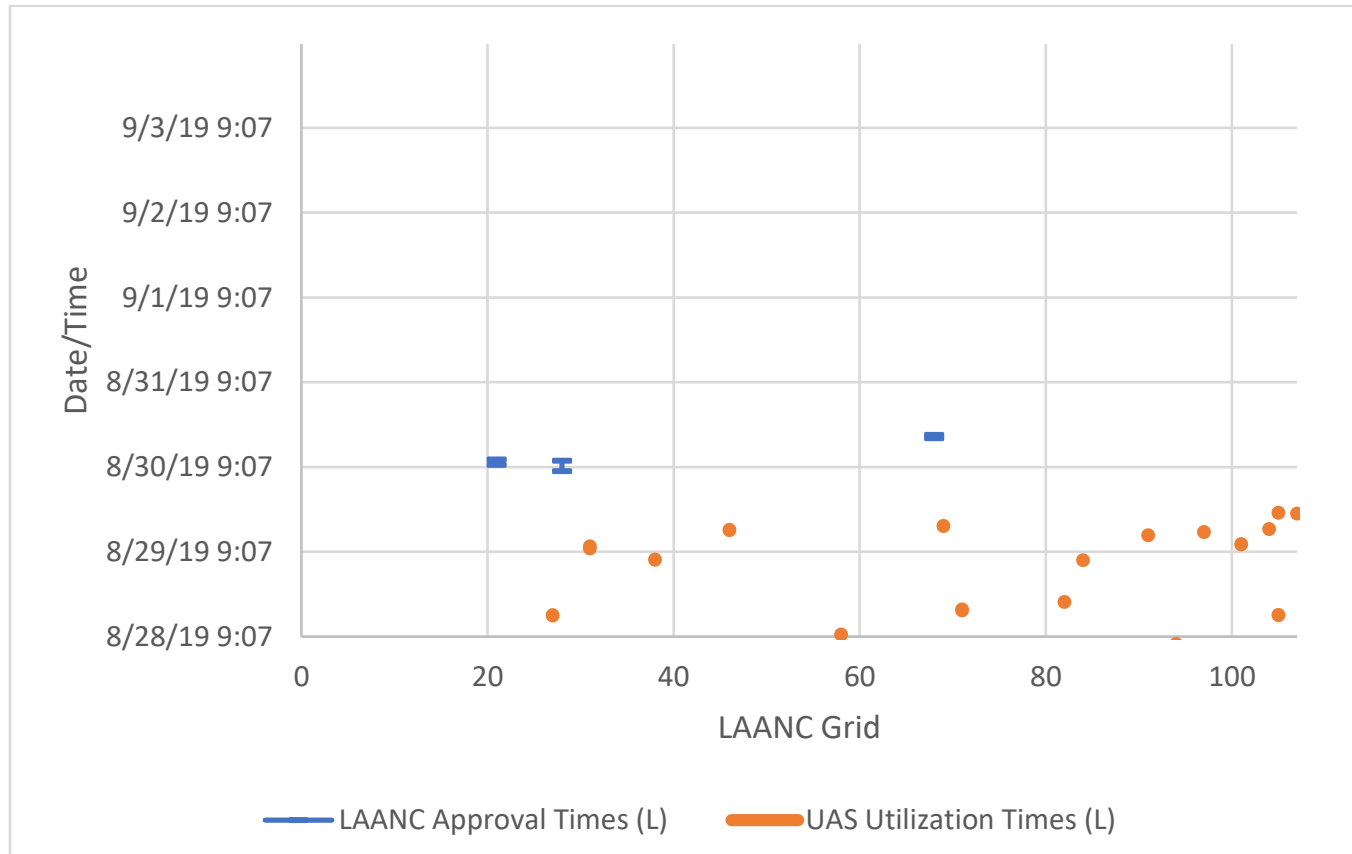

Figure 17. Low Altitude Authorization \& Notification Capability Utilization, KDAB, 28 Aug 19 0900L - 4 Sep 19 0859 L. 


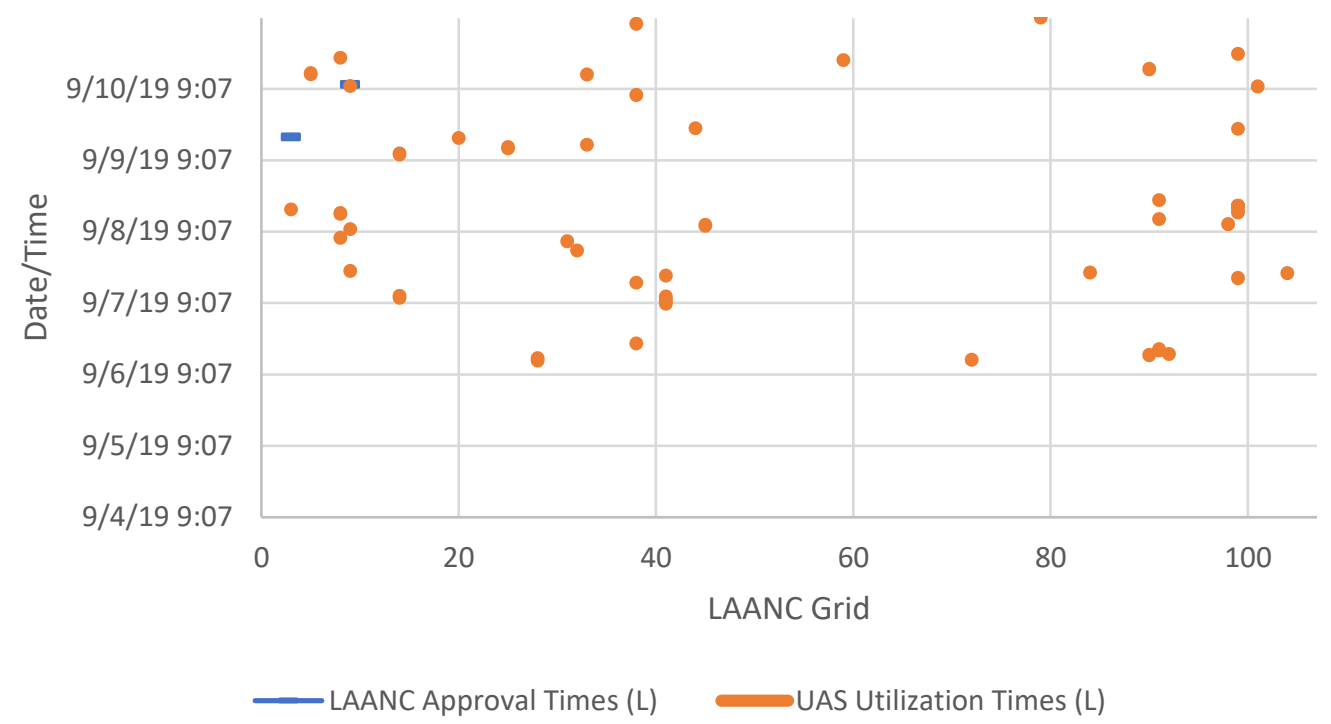

Figure 18. Low Altitude Authorization \& Notification Capability Utilization, KDAB, 4 Sep 19 0900L - 11 Sep 19 0859 L.

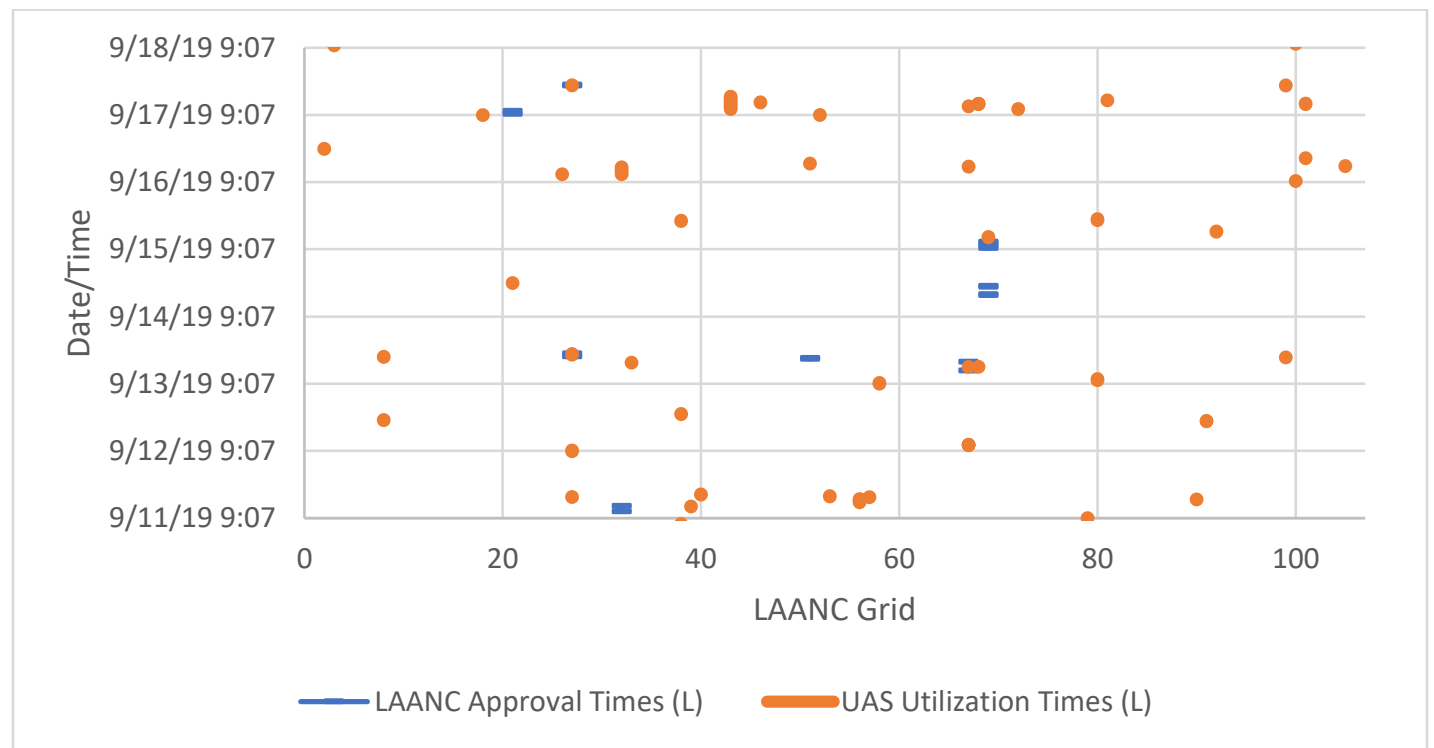

Figure 19. Low Altitude Authorization \& Notification Capability Utilization, KDAB, 11 Sep 19 0900L - 18 Sep 19 0859 L. 


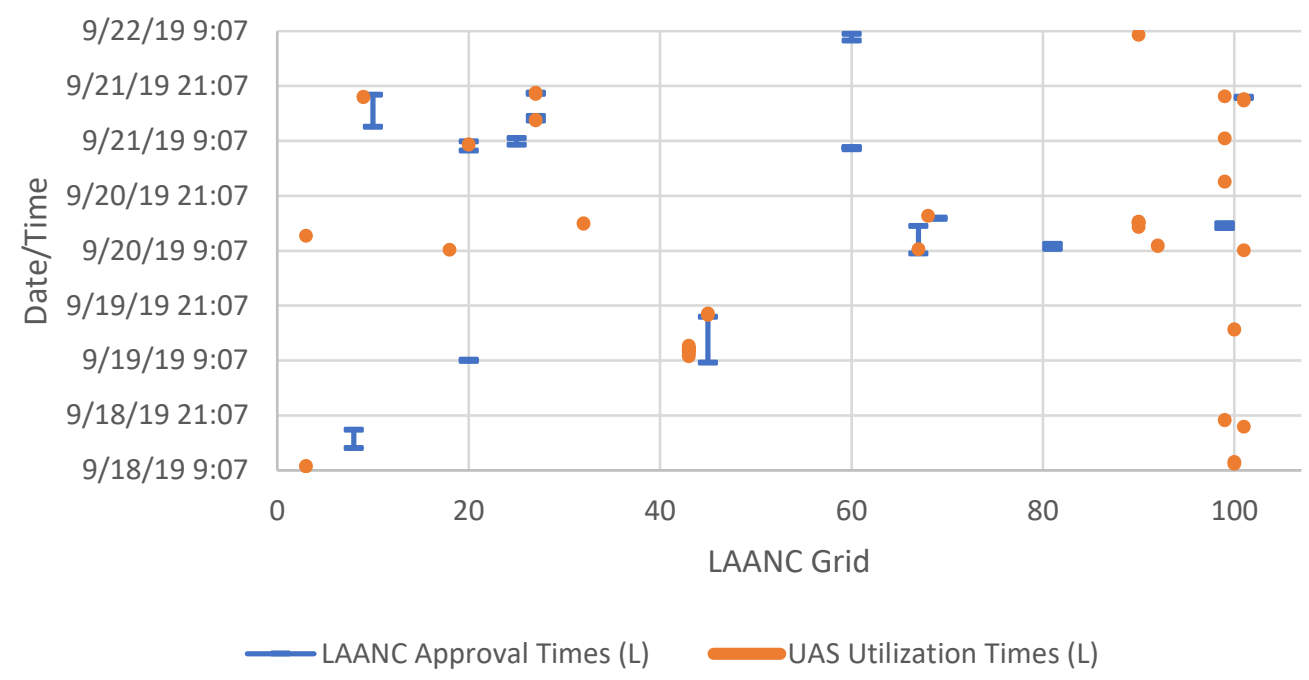

Figure 20. Low Altitude Authorization \& Notification Capability Utilization, KDAB, 18 Sep 19 0900L - 22 Sep 19 0859 L.

\section{Conclusions}

What proportion of detected UAS activity carried out in controlled airspace can be correlated to a LAANC authorization?

Only 19 LAANC authorizations could be correlated to UAS activity among the 65 automated LAANC approvals. It was somewhat surprising that UAS activity was detected during only $29.2 \%$ of LAANC authorization times. Several possible explanations were previously presented for this anomaly, including: (1) UAS not flown during LAANC authorization; (2) UAS not detectable by AeroScope UAS detection device; or (3) mismatching LAANC authorization location and UAS launch location.

More notable, however, was the quantity of UAS activity that was carried out outside LAANC approval locations and times. The collected data for the sample location suggests that only about $7.0 \%$ of detected UAS could be correlated to a LAANC authorization. For the sample location included in this study, this means 252 UAS flight operations could not be correlated to a LAANC authorization. The quantity of UAS flight operations taking place outside the scope of established FAA approval and safety management processes may indicate that current regulatory mechanisms designed to control UAS operator access to controlled airspace may not be working. 
It is notable however, that some operations may still be conducted in compliance with FAA regulations outside of the LAANC system under the following conditions:

- UAS operator received a manual Wide-Area LAANC authorization, permitting operation in any LAANC grid area without receiving automated approval, provided flight occurs below the maximum altitude for that respective UASFM grid.

- UAS operator is operating under authority of a 14 CFR $\$ 107.41$ airspace waiver, as outlined by 14 CFR $\S 107$, Subpart D.

What proportion of detected UAS activity exceeds the maximum prescribed altitudes of the UAS Facility Map?

Of the 271 UAS flights, 93 (34.3\%) were detected above the maximum UAS Facility Map prescribed altitude for their respective location. Moreover, of the 93 UAS operations detected above UASFM maximum altitudes, 39-14.4\% of all detected UAS operations - exceeded UASFM maximums by less than 100 feet. Since most manned aircraft flights would be subject to 14 CFR $\$ 91.119$ (b) [1,000 $\mathrm{ft}$, over congested areas] or (c) [500 ft, over other than congested areas] minimum safe altitude limitations, even these UAS flights marginally exceeding UASFM limits would be unlikely to pose a particularly serious hazard to the National Airspace System. Researchers detected 41 UAS operations exceeding 500 feet AGL (15.1\%), which poses a greater risk to manned aircraft in the National Airspace System. Of these UAS operations, 32 (11.8\%) were between 500-1,000 feet AGL; 6 (2.2\%) were detected from 1,000-1,500 feet AGL; and $3(1.1 \%)$ exceeded 1,500 feet AGL.

\section{Recommendations}

This research highlights notable gaps in effectiveness and compliance with existing FAA policies for integrating small unmanned aircraft systems into the lowaltitude region of the National Airspace System. The research team recommends the adoption of additional proactive measures to curtail non-compliant operations, including formal and informal UAS operator education [FAAST Courses, Waiver Videos, etc], liberal use of deterrent measures [such as no drone zone signage or social media outreach], and continual promotion of UAS operator compliance tools [B4UFLY, FAA DroneZone, etc]. The research team also believes more stringent UAS operator enforcement measures are also warranted.

In December 2019, the Federal Aviation Administration released a notice of proposed rulemaking to establish 14 CFR $\S 89$, Remote Identification of Unmanned Aircraft Systems. This rulemaking action would formalize requirements for mandatory tracking of most small unmanned aircraft systems operating in the 
National Airspace System. The new rule is anticipated to increase safety and security within the National Airspace System, by improving stakeholder situational awareness of UAS operations. It remains to be seen if Remote Identification will equip the Federal Aviation Administration, law enforcement, and other stakeholders with the means to effectively curtail hazardous or malicious UAS operations.

\section{Future Research}

The authors intend to replicate this study at additional airports within the U.S. to validate findings. Aggregated data will be used to inform decision-makers and advise UAS operational policy development. 


\section{References}

Clark, B. (2019). Earthpoint: Excel to KML - display excel files on Google Earth. Retrieved from http://www.earthpoint.us/ExcelToKml.aspx

Drone Industry Insights. (2019). Infographic: Drone manufacturers market shares USA. Retrieved from https://www.droneii.com/project/dronemanufacturers-market-shares-usa

FAA Modernization \& Reform Act of 2012, Pub. L. 112-95, 126 Stat. 11, codified as amended at 49 U.S.C. 40101

Hofacker, C. (2019). For hobbyists in the U.S., the wild west comes to an end. Aerospace America. Retrieved from https://aerospaceamerica.aiaa.org/fordrone-hobbyists-in-the-u-s-the-wild-west-comes-to-an-end/

Karpowics, J. (2019). Signaling the end of the "wild west" for drones in the airspace. Commercial UAV News. Retrieved from https://www.expouav.com/news/latest/signaling-the-end-of-the-wild-westfor-drones-in-the-airspace/

Law360. (2019). Is the US ready for a 'Gatwick Drone' scenario. Wiley Rein. Retrieved from https://www.wileyrein.com/newsroom-articles-IsThe-US-Ready-For-A-Gatwick-Drone-Scenario.html

Levin, A. (2018). Drone hobbyists angered by Congress ending aerial wild west. Bloomberg. Retrieved from https://www.bloomberg.com/news/ articles/2018-09-27/drone-hobbyists-angered-by-congress-ending-theaerial-wild-west

Federal Aviation Administration. (2019a). Air traffic facilities participating in $L A A N C$. Retrieved from https://www.faa.gov/uas/programs_partnerships/ data_exchange/laanc_facilities/

Federal Aviation Administration. (2019b). FAA UAS facility map data (V2). Retrieved from https://uas-faa.opendata.arcgis.com/search

Federal Aviation Administration. (2019c). FOIA library: Geographic listing of hobbyist / non-hobbyist sUAS registry enrollments and registrants. Retrieved from https://www.faa.gov/foia/electronic_ reading_room/

Federal Aviation Administration. (2019d). LAANC drone program expansion continues. Retrieved from https://www.faa.gov/news/updates/ ?newsId $=94750$

Federal Aviation Administration. (2019e). Low altitude authorization and notification capability - LAANC [ATO Policy N JO 7210.914]. Retrieved from https://www.faa.gov/documentLibrary/media/Notice/ N_JO_7210.914_Low_Altitude_Authorization_and_Notification_Capabili ty_-_LAANC.pdf 
Federal Aviation Administration. (2019f). More access to airspace to fly drones. Retrieved from https://www.faa.gov/news/updates/ ?newsId=93789

Federal Aviation Administration. (2019g). UAS data exchange (LAANC). Retrieved from https://www.faa.gov/uas/programs_partnerships/ data_exchange/

Federal Aviation Administration. (2019h). UAS sightings report. Retrieved from https://www.faa.gov/uas/resources/public_records/ uas_sightings_report/

Request for Emergency Processing of Collection of Information by the Office of Management and Budget: Emergency Clearance to Revise Information Collection 2120-0768, Part 107 Authorizations and Waivers. 82 Fed. Reg. 47289 (October 11, 2017).

Rupprecht, J. (2019). FAA's LAANC system-(low altitude authorization \& notification capability). Retrieved from https://jrupprechtlaw.com/lowaltitude-authorization-notification-capability-laanc-system/

Skylogic Research. (2018). 2018 drone market sector report. Retrieved from https://droneanalyst.com/research 